\title{
Integrated Reporting Compliance With The Global Reporting Initiative Framework: An Analysis Of The South African Mining Industry
}

Tertia Hindley, Deloitte, Johannesburg, South Africa

Pieter W Buys, Ph.D., North-West University, South Africa

\begin{abstract}
For all financial years ending on or after March $1^{\text {st }} 2010$, all companies listed on the Johannesburg Stock Exchange Ltd (JSE) have to provide an Integrated Report (as part of the JSE's listing requirements). This report is to supply sustainability information in addition to the conventional IFRS-based statements. Yet, no statutory requirement for adherence to reporting standards relating to sustainability exists. This creates the risk that sustainability reports will omit negative impacts or be otherwise misleading, yet the company is still seen as adhering to listing and thus statutory requirements. This article considers the quality of integrated reporting of the South African mining industry by evaluating compliance to the globally accepted Sustainability Framework of the Global Reporting Initiative, which includes Sector specific performance indicators, as well as GRI core indicators. Using a sample of the mining companies included in the JSE Top 40 companies, the results show that these companies used the GRI G3.1 version guidelines in producing their integrated reports and that adherence to the GRI guideline has improved over the two years under consideration.
\end{abstract}

Keywords: Corporate Social Responsibility; Financial Reporting; GRI Framework; Integrated Reporting; Sustainability; Triple-Bottom-Line

\section{INTRODUCTION}

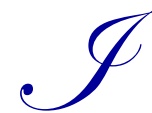
$\mathrm{n}$ the global business and economic contexts, long-term sustainability has become very important as a basis for investment decisions, and consumers are growing more conscious of the social and environmental performances of the entities from whom they buy goods and/or services (Ho \& Taylor, 2007). Ho and Taylor (2007) also stated that evaluating organizational performances based on economic factors alone, are no longer sufficient because stakeholders are more and more concerned about whether a company is being socially responsible and environmentally friendly.

Not too long ago, a company would have been considered as an exemplary, well performing organization if it could deliver its products and services, publish an annual report and distribute dividends, but no longer (Deloitte, 2011a). Lev and Zarowin (1999) also indicated that the usefulness of financial information to investors and other stakeholders have been deteriorating due to the increasing demand from stakeholders for relevant information. Eccles and Krzus (2010) stated that reporting is of much importance since it communicates to the outside world its performance and its plans and objectives for the future. Oberholzer (2011) even goes as far as comparing data to gasoline - getting insufficient or bad data (or not understanding the data) is like running out of gas. The effective reporting of company information is therefore not only essential to management functions like planning and control, but also to the external stakeholder decision-making processes. Today there are growing expectations for companies not to simply turn a profit. The reporting of stakeholder relevant company information therefore comes down to one fundamental principle: the on-going search for effective communication. What is required is a report that provides integrated and relevant information to the broader base of stakeholders. 
The Global Reporting Initiative (GRI) used the principles of social responsibility and economic, social and environmental impacts in their approach to create a framework for reporting on sustainability. Integrated reports that are based on the GRI's Sustainability Framework will indicate a company's commitment to sustainable development and will enable users thereof to compare the performance of the company over time as well as to measure the company's adherence to applicable laws, standards, principles and voluntary initiatives (GRI, 2011a). The GRI (2011a) stated that it endorses standardized reporting of sustainability information which benefits both the reporting company as well as the users of the report. According to their mission statement the GRI also strives to make sustainability reporting standard practice (GRI, 2011b).

In response to the growing importance of sustainability reporting, the Johannesburg Stock Exchange Ltd (JSE) added as a listing requirement that all JSE listed companies have to adhere to the King III Code of Governance. This entails (amongst other things) providing an integrated report, consisting of a report on the company's sustainability in addition to its conventional International Financial Reporting Standards (IFRS) based reports for all financial years ending on or after 1 March 2010 (SAICA, 2011). Unfortunately, many executives do not know exactly what concepts such as sustainability, corporate social responsibility (CSR), and triple bottom-line (TBL) entail (Abouzeid \& Weaver, 1978). In Abouzeid and Weaver's (1978) earlier survey entitled The Most Important Corporate Goals Identified by Participating Companies, the polled executives did not select CSR as an important business goal but they did however, select customer satisfaction, employee welfare and safety as important goals. It is evident that this lack of clarity remained a problem throughout the years seeing as, even with many great minds applied to the science of sustainability and integrated reporting, a full understanding of how to approach sustainability, while still ensuring growth, has still to be obtained (Pounder, 2011; Doane \& MacGillivray, 2001). Doane and MacGillivray (2001) also stated that managers need to better understand what it is that makes a business survive, what finance directors need to be aware of regarding sustainability and other factors that need to be considered when a business appears to be struggling, that sustainability is not left behind in an attempt to save the company.

In the South African context, the Mining and Minerals industry includes the companies with the highest environmental impacts; Sasol, BHP Billiton, ArcelorMittal SA and Anglo American being amongst the top 5 companies with regards to high $\mathrm{CO}_{2}$ emissions (National Treasury, 2010). South Africa is the world's largest platinum producer and one of the leading producers of base metals, coal, gold and diamonds, and also holds the largest natural reserves of chrome ore, manganese ore, gold and platinum-group metals (SouthAfrica.info, 2012). Furthermore, according to the Chamber of Mines of South Africa (2011) the following contributions can be attributed to the industry in 2010:

- $\quad 8.6 \%$ direct contribution to the GDP of South Africa with a further $19 \%$ indirect contribution;

- $\quad$ Over $50 \%$ of merchandise exports;

- $\quad$ Approximately $20 \%$ of gross investment;

- About $30 \%$ of the capital inflows into the economy, and

- $\quad 94 \%$ of South Africa's electricity generating capacity.

Considering the above, the Mining and Minerals industry is not only of importance to the broader Southern African economy (and the global economies), but it also has a significant impact on the environmental and the social development initiatives of the region.

\section{RESEARCH OBJECTIVE}

Considering the above, the question can be asked as to the extent to which the integrated reports of the South African Mining and Minerals companies, as submitted to the JSE, have been prepared in compliance with, and in consideration of, the GRI guidelines. In meeting this objective, the following aspects have to be considered. Firstly, the key aspects reported on by the companies have to be identified, secondly the level of integration of the sustainability reports with the conventional annual financial statement has to be evaluated, and thirdly the applicable rating ('A', 'B' or 'C') given to the applicable reports, needs to considered. 
By analysing and comparing the Integrated Reports provided by the Mining and Mineral companies listed on the JSE, together with the GRI's Sector Supplements for Mining and Metals companies, it should therefore be possible to determine the extent to which these companies' integrated reports adhere to the G3.1 Guidelines Sector Supplement for Mining and Metals companies.

\section{RESEARCH METHODOLOGY}

A quantitative, applied and descriptive research methodology will be followed in order to address the stated objectives. The reports of the Mining and Minerals companies listed on the Top 40 companies (2010 and 2011 financial years) of the JSE have been identified as the sample to be used in the report analysis based on the GRI G3.1 Sector Supplements for Mining and Metals companies. The relevant company reports were obtained from their respective websites. All listed companies are required to issue their annual reports within 6 months of the date of their financial year end. Furthermore the requirement to issue integrated reports is for all financial years ending on or after 1 March 2010. Thus 2010 reports will be used as basis to gauge whether integrated reports have been submitted. In addition to this, 2011 reports will also be used in order to be able to judge comparability and improvements in reporting on a per company basis.

In order to meet these objectives, the article is set out in the following manner. Firstly, an overview of the theoretical framework is provided, which includes overviews of corporate social responsibility, triple-bottom-line reporting, sustainability and integrated reporting. This is followed by a high level overview of the G3.1 Sustainability Framework as the literature component of the research conducted, which is in turn followed by the research results before the final conclusions and recommendations.

\section{THEORETICAL FRAMEWORK}

\section{Corporate Social Responsibility}

According to Two Tomorrows (2009) (previously known as the CSR Network), the concept of Corporate Social Responsibility is about how companies align their principles, values and actions with that what is expected from them by all its stakeholders (i.e. it is not just about shareholders but also about customers, suppliers, investors, employees, regulators, groups with special interests and anyone affected by the company in any significant manner). Adams et al (1998) examined CSR practices of numerous European companies, and found that these companies typically categorize their disclosures into several key aspects including reporting on environmental aspects, on employee aspects and on ethical aspects. It thus indicates the commitment of a company to be accountable to all stakeholders.

According to Pounder (2011), Borkowski et al. (2010) and Swift et al. (2007), the terms sustainability (discussed in more detail below) and CSR are often used interchangeable. Sustainability however, is described as a broader concept that seeks long-term economic, natural and social capital growth, whereas CSR is more focused on shorter-term tendencies, problems and activities (e.g. philanthropy, adherence to legalities and improvement in working conditions). Thus many companies may claim to be socially responsible, but there are few that are truly sustainable (Swift et al. (2007). Two Tomorrows (2009) also clearly indicate that CSR demands that, in order to maximize benefits and keep downsides to minimum, companies have to manage the economic, social and environmental impacts of their operations.

\section{Triple-Bottom-Line reporting}

The term triple-bottom-line was originally coined by John Elkington, a management consultant (Rogers \& Ryan, 2001), and is an attempt to acknowledge the interaction of three key interest areas in the continued existence of the company, which are according to Elkington (1997) not only about pursuing economic success, but about simultaneously pursuing environmental quality and social equity as well, hence the concept of the triple-bottom-line.

While conventional financial statements primarily focus on profitability and financial indicators, TBL reporting attempts to present a broader view of the corporate economic interactions with all its stakeholders (Ho \& 
Taylor, 2007). Therefore, companies that want to achieve sustainability cannot only measure its performance against a single financial bottom line, but against all the TBL components, i.e. the social bottom line (or the people aspect), the economic bottom line (or the profitability) and the environmental bottom line (or the planet aspect) (Elkington, 1997). Thus, in the context of the TBL, all three these concepts need to be considered equally in order to achieve long-term organizational sustainability.

\section{Sustainability}

According to Deloitte (2009), the King II Code on Governance in South Africa illuminated corporate citizenship and integrated sustainability, in terms of which a company needs to account for its environmental and social issues as well as economic performances. The King III Code on Governance in South Africa expanded here upon by emphasizing the concept of sustainability. Deloitte's interpretation of King III's focus is that directors are accountable to all stakeholders in order to assure that the company's resources are utilized in such a way that it will be able to continue to be viable. This involves environmental sustainability, social responsibility, respect for human rights and the successful managing of stakeholder's relationships (Deloitte, 2009; King III, 2009).

If the growth in population, resource consumption and economies continue at its current rates, the resources of the world will be depleted to such an extent that it will no longer be able to support life (Swift et al., 2007), and this makes sustainability relevant to all of us. According to Swift et al. (2007), a company or activity is considered unsustainable when its continued activity would result in the exhaustion of a given resource. Swift et al. (2007) also stated that sustainable development is of high political importance in many governments and that failure to adhere to sustainable development objectives can expose a company to strategic, business and reputational risks, which can result in the loss of stakeholders' trust, increases in cost of capital and in extreme cases even the loss of the ability to operate as a going concern.

King III (2009) specifically includes the principle of TBL reporting as a part of sustainability, but states that sustainability is more than just reporting on sustainability and that it is vital for companies to focus on integrated reporting. The King III Code of Governance (King III, 2009) thus supports the notion of sustainability reporting but acknowledges that in the past sustainability reporting was done in addition to financial statements, whereas the current position is that sustainability reporting must be integrated with the financial statements.

\section{Integrated Reporting}

According to Deloitte (2011b) integrated reporting attempts to incorporate everything from risk management through to strategy, and from financial reporting to the utilization of other capital sources. It therefore seeks to meet the needs of a broader group of stakeholders - thus everyone associated with the company is likely to be affected by it. Deloitte (2011b) also highlights that the integrated report is simply an output of extensive prior reporting initiatives and consider it as the enabler of a process which improves and preserves long-term sustainability in all aspects, without unduly leading to the sacrifice of short-term performance. At the very essence of integrated reporting lies the Integrated Report that in time will become the primary report of all companies (Deloitte, 2011b). The jury however, is still out as to what exactly the format hereof should be, and whether certain components of the conventional reports will be moved to online sources and what the actual information included in the report will be.

Even with numerous terms, definitions and explanations as indicated above, one can still be unsure as to what needs to be reported on, and how it needs to be reported on, in order for an integrated report to be seen as sufficient. As mentioned earlier, the Sustainability Reporting Framework, as developed by the GRI, can be used to assist companies with their integrated reporting initiatives. 


\section{THE GRI's SUSTAINABILITY REPORTING FRAMEWORK}

\section{Components of the Framework}

The GRI's Sustainability Reporting Framework (hereafter the Framework) prescribes the minimum disclosures needed in order to produce comparable and complete sustainability reports. In its essence, it may be argued that the integrated report is a combination of the sustainability reporting concepts as suggested by the GRI, and the conventional financial reporting aspects as required by IFRS. The Framework consists of several sections (GRI, 2011c), including:

- $\quad$ The Sustainability Reporting Guidelines. These Guidelines form the foundation and corner stone of the Framework, which are now in their third generation, called G3.1. The G3.1 Guidelines are available are freely available at no cost (GRI, 2011a).

- The Sector Supplements. For certain sectors, the abovementioned Guidelines have been expanded to address sector specific aspects and issues. The currently available Supplements include the Mining and Metals industry (GRI, 2011d).

- The Technical Protocol. The Protocol guides the reporting company through the process of defining the contents of the sustainability report (a requirement of the Sustainability Reporting Guidelines).

Expanding on the above, the Sustainability Reporting Guidelines (as listed above) also recommend certain Standard Disclosures, which are typically the minimum suggested disclosures of the economic, environmental and social impacts. Within each of these economic, environmental and social considerations, the company should highlight its strategy, management's approach and the performance indicators for each. The first two considerations (i.e. the strategy and the management approach) may typically be considered as generic, whereas the performance indicators are then more specific in their consideration and reporting of actual results. The various performance indicators are further classified into the core indicators and the additional indicators (GRI, 2011e). Firstly, the core indicators are those considered being of key interest to most stakeholders and they are thus assumed to be material unless deemed otherwise. Secondly, the additional indicators are those indicators that address topics that may be material to some companies and/or stakeholders but not generally for the majority of companies and/or stakeholders. These additional indicators may also be representative of emerging practices and are therefore not (yet) considered to be material (GRI, 2011e).

Therefore, in the analysis of the integrated reports of the South African Mining and Minerals industry, the Sector Specific Performance indicators (as per the above mentioned Sector Supplements) and the Core indicators (as per the Sustainability Reporting Guidelines section on performance indicators) have been taken into account in consideration of the compliance to the G3.1 Guidelines.

\section{Application levels of the Framework}

In order for a company to indicate that its Sustainability Report have been prepared on the basis of the GRI Guidelines as discussed above, the company should declare the level of such adherence using the GRI's application levels system (GRI, 2011f). There are currently three levels of application available named 'A', 'B' and 'C', (see Table 1 below), with ' $\mathrm{A}$ ' indicating the highest level of compliance and adherence to the Framework, ' $\mathrm{B}$ ' being the midway level and ' $\mathrm{C}$ ' being the lowest level of adherence. In the case where external assurance was obtained with regards to the sustainability report, a '+' sign is added to the application level as indication of such assurance (GRI, 2011f, Borkowski et al.). 
Table 1: GRI Sustainability Reporting Framework adherence levels

\begin{tabular}{|c|c|c|c|c|c|c|}
\hline & $\bar{C}$ & $\overline{\mathrm{C}+}$ & B B & $\mathbf{B +}$ & $\overline{\mathbf{A}}$ & A+ \\
\hline Profile Disclosures & $\begin{array}{l}\text { Report on indicators: } 1.1 \text {, } \\
2.1-2.10,3.1-3.8, \quad 3.10- \\
3.12,4.1-4.4,4.14-4.15\end{array}$ & \multirow{3}{*}{ 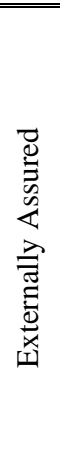 } & $\begin{array}{l}\text { In addition to 'C', also } \\
\text { report on indicators: } 1.2 \text {, } \\
3.9,3.13,4.5-4.13,4.16- \\
4.17\end{array}$ & \multirow{3}{*}{ 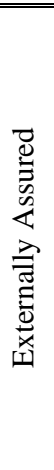 } & Same as for 'B' & \multirow{3}{*}{ 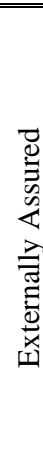 } \\
\hline $\begin{array}{l}\text { Disclosures on } \\
\text { Management } \\
\text { approach }\end{array}$ & Not Required & & $\begin{array}{l}\text { Management approach } \\
\text { i.r.o. each indicator } \\
\text { category }\end{array}$ & & $\begin{array}{l}\text { Management approach } \\
\text { i.r.o. each indicator } \\
\text { category }\end{array}$ & \\
\hline $\begin{array}{l}\text { Performance } \\
\text { Indicators \& Sector } \\
\text { Supplement } \\
\text { Performance } \\
\text { Indicators }\end{array}$ & $\begin{array}{l}\text { Report on at least } 10 \\
\text { performance indicators (at } \\
\text { least one from each of: } \\
\text { social, economic and } \\
\text { environment). }\end{array}$ & & $\begin{array}{l}\text { Report on at least } 20 \\
\text { performance indicators } \\
\text { (at least one from each of: } \\
\text { social, economic and } \\
\text { environment). }\end{array}$ & & $\begin{array}{l}\text { Report on each core and } \\
\text { sector supplement } \\
\text { indicator or explain the } \\
\text { reason for its omission. }\end{array}$ & \\
\hline
\end{tabular}

Source: Adapted from GRI (2011f)

According to the GRI (2011f), companies are required to make a self-declaration of their level of adherence and compliance, which can then either be substantiated by having a third party express an opinion on the report or by requesting the GRI to check the self-declaration. For each company included in the research sample, the above table has been used in order to gauge adherence to the GRI Sustainability Framework:

\section{RESEARCH RESULTS}

\section{Descriptive statistics}

The selected sample consisted of 13 companies in the Mining and Minerals industry (per the JSE Top 40 listing as at 15 August 2011). All companies had issued 2010 as well as 2011 reports by the end of July 2012, thus making both improvement and comparability analyses possible (see Table 2 below). Compliance with the Core as well as the Sector Specific Indicators was tested by an analysis of the respective reports. Based on the Framework, a total of up to 63 performance indicators may be reported on, of which 52 are Core and 11 are Sector Specific indicators.

Table 2: JSE listed Mining and Minerals companies' reporting indicators

\begin{tabular}{|c|c|c|c|c|c|c|}
\hline \multirow[b]{2}{*}{ Company } & \multicolumn{3}{|c|}{2010} & \multicolumn{3}{|c|}{2011} \\
\hline & $\begin{array}{c}\text { Core } \\
(n=52)\end{array}$ & $\begin{array}{c}\text { Sector } \\
\text { Specific } \\
(n=11)\end{array}$ & $\begin{array}{c}\text { Total } \\
(n=63)\end{array}$ & $\begin{array}{c}\text { Core } \\
(n=52)\end{array}$ & $\begin{array}{c}\text { Sector } \\
\text { Specific } \\
(n=11)\end{array}$ & $\begin{array}{c}\text { Total } \\
(\mathbf{n}=63)\end{array}$ \\
\hline Arcelormittal & 32 & 0 & 32 & 31 & 3 & 34 \\
\hline Anglo American & 52 & 11 & 63 & 52 & 11 & 63 \\
\hline Anglo Platinum & 52 & 10 & 62 & 52 & 10 & 62 \\
\hline Anglo Gold & 50 & 11 & 61 & 50 & 11 & 61 \\
\hline Arm-African Rainbow & 45 & 9 & 54 & 51 & 11 & 62 \\
\hline Bhp Billiton & 52 & 11 & 63 & 51 & 11 & 62 \\
\hline Exxaro Resources Ltd & 46 & 4 & 50 & 44 & 9 & 53 \\
\hline Glodfields Ltd & 52 & 11 & 63 & 52 & 11 & 63 \\
\hline Harmony Gold & 43 & 0 & 43 & 52 & 0 & 52 \\
\hline Implats & 31 & 0 & 31 & 37 & 0 & 37 \\
\hline Kumba Iron Ore Ltd & 24 & 0 & 24 & 52 & 10 & 62 \\
\hline Lonmin & 52 & 11 & 63 & 52 & 11 & 63 \\
\hline Sasol & 52 & 11 & 63 & 52 & 11 & 63 \\
\hline
\end{tabular}

The above results indicate that six companies reported on all 52 the Core indicators in 2010, while seven companies did so in 2011. In respect of the Sector Specific indicators, six companies reported on all 11 indicators, with seven companies in 2011. Note that these are not necessarily the same companies in both years. A little concerning was the fact that four companies did not provide any information on the Sector Specific indicators in 
2010. There was however some improvement with two of these companies reporting on at least some of these indicators in 2011.

\section{Key performance indicators reported on.}

In analysing the data to gauge the key indicators reported on, it became evident that certain indicators have been reported on by all companies. These have thus been identified as the key indicators, being those that all companies considered of high enough materiality and importance to measure and report on.

Table 3: Key performance indicators reported on

\begin{tabular}{|c|c|c|c|}
\hline Code & Description & 2010 & 2011 \\
\hline EC 1 & Direct economic value generated and distributed & Yes & Yes \\
\hline EC 2 & Financial implications and risks due to climate change & & Yes \\
\hline EC 6 & Policies and proportion of spending on local suppliers & Yes & \\
\hline EC 8 & Investments and services provided for public benefit & Yes & Yes \\
\hline EN 3 & Direct energy consumption & Yes & Yes \\
\hline EN 8 & Total water withdrawal & Yes & Yes \\
\hline EN 16 & Total direct and indirect greenhouse gas emissions & Yes & Yes \\
\hline EN 22 & Total weight of waste & & Yes \\
\hline LA 1 & Total workforce by employment type & & Yes \\
\hline LA 4 & Percentage of employees covered by collective bargaining agreements & Yes & Yes \\
\hline LA 7 & Rates of occupational injuries, diseases and fatalities & Yes & Yes \\
\hline LA 10 & Average hours of training per employee & Yes & Yes \\
\hline LA 13 & Composition of governance bodies and employees according to indicators of diversity & & Yes \\
\hline HR 6 & Operations having significant risk of child labour & Yes & Yes \\
\hline HR 7 & Operations having significant risk of forced and compulsory labour & & Yes \\
\hline SO 1 & Effectiveness of practices that assess and manage impacts of operations on communities & & Yes \\
\hline SO 5 & Position and participation in public policy development and lobbying & & Yes \\
\hline
\end{tabular}

As per Table 3, these indicators include issues more widely known as sustainability concerns which indicate that public perception of what sustainability is, has a major impact on what is reported on by companies. It can be seen that of the top key performance indicators reported on, four were economic in nature (see the 'EC' indicators), four were environmental in nature (see the ' $\mathrm{EN}$ ' indicators), five were labour related (see the 'LA' indicators), two were human rights related (see the 'HR' indicators), and two were socially orientated (see the 'SO' indicators).

\section{Level of Integration}

The Integrated Reporting Committee (IIRC) stated that an Integrated Report is aimed at combining the different threads of reporting (e.g. financial, management, governance and sustainability reporting) into a comprehensible whole that can explain a company's ability to create and/or sustain value (Deloitte, 2012). It should also be seen as a process of improving and persevering sustainability in the long term without the sacrificing of a company's short-term performance (Deloitte, 2012). This report should be an all-inclusive integrated annual report that illuminates the company's efforts towards long-term sustainability in all its dimensions. The Integrated Report should therefore contain both qualitative and quantitative information on how, and to which extent, the reporting company has managed to improve its economic, environmental and social effectiveness and efficiency (Daub, 2007), which need to be integrated in a sustainability management system.

The concept integrated does not simply indicate that all the relevant information be combined into a single report. As long as the holistic picture is disclosed, an integrated report can even be divided into multiple reports. However, if a company was to choose the multiple reports option, a reference to the other parts of the report, or to the more detailed separate report, needs to be made in order for users and stakeholders not to be misled in thinking that the reporting company issued only one report. During the analysis of the companies' reports, the physical compilation of the reports was taken into consideration. The following categories of integration were identified: 
- $\quad$ Fully Integrated: This refers to a single integrated report that includes all necessary information needed to form a holistic view of the company's financial as well as its sustainability performances.

- Integrated and Separate: This refers to a single integrated report that serves the above mentioned purpose, but with references to separate documents that include more detail on certain areas. The additional separate reports often include the detailed sustainability reports, corporate governance reports.

- Separate: This indicates that a company compiled separate reports for financial and non-financial disclosures. Thus a separate sustainability report was created in addition to the normal financials.

- Separate on Web: This indicates that non-financial information is disclosed but not as part of the annual report. This information is only available on the company's website.

After analysis of the applicable entities' reports the following categorization was made and reported in Table 4 below:

Table 4: Level of integration per company

\begin{tabular}{|c|c|c|c|c|c|c|c|c|}
\hline \multirow[b]{2}{*}{ Company } & \multicolumn{4}{|c|}{2010} & \multicolumn{4}{|c|}{2011} \\
\hline & 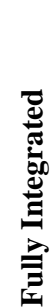 & 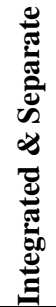 & 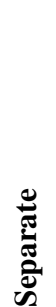 & 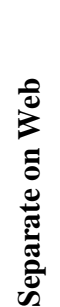 & 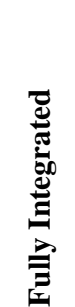 & 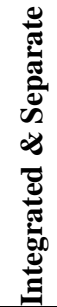 & 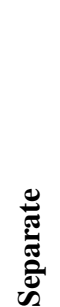 & 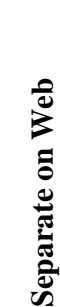 \\
\hline Arcelormittal & & 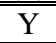 & & & & 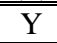 & & \\
\hline Anglo American & & & $\mathrm{Y}$ & & & & $\mathrm{Y}$ & \\
\hline Anglo Platinum & & & $\mathrm{Y}$ & & & $\mathrm{Y}$ & & \\
\hline Anglo Gold & & & $\mathrm{Y}$ & & & $\mathrm{Y}$ & & \\
\hline Arm - African Rainbow & & $\mathrm{Y}$ & & & & $\mathrm{Y}$ & & \\
\hline Bhp Billiton & & $\mathrm{Y}$ & & & & $\mathrm{Y}$ & & \\
\hline Exxaro Resources Ltd & $\mathrm{Y}$ & & & & $\mathrm{Y}$ & & & \\
\hline Glodfields Ltd & & $\mathrm{Y}$ & & & $\mathrm{Y}$ & & & \\
\hline Harmony Gold & & & & $\mathrm{Y}$ & & & & $\mathrm{Y}$ \\
\hline Implats & $\mathrm{Y}$ & & & & & $\mathrm{Y}$ & & \\
\hline Kumba Iron Ore Ltd & & & $\mathrm{Y}$ & & & $\mathrm{Y}$ & & \\
\hline Lonmin & & & $\mathrm{Y}$ & & & & $\mathrm{Y}$ & \\
\hline Sasol & & $\mathrm{Y}$ & & & & $\mathrm{Y}$ & & \\
\hline Total & 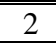 & 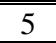 & 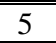 & 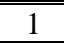 & 2 & 88 & 2 & $\overline{11}$ \\
\hline
\end{tabular}

In terms of what is regarding high-quality reports, both the Fully Integrated reports as well as Integrated and Separate reports are regarded as acceptable reports. When using only a Separate report, specific reference needs to be made to the other reports containing non-financial information. This is also applicable when using Separate on Web reports with references needed to the sectional reports in the annual report to ensure that users are aware of all applicable reports. When considering the findings in the Mining and Minerals industry, seven of the companies submitted acceptable integrated reports in 2010, with an improvement of three additional companies moving towards Integrated and Separate reports in 2011, which are better, albeit still somewhat separate.

\section{Self-declared ratings}

The final analysis conducted in this study was to analyse the adherence levels of the various reports. The integrated reports were evaluated based on the sustainability disclosure requirements as per the GRI, which were then compared against the companies' own assessment of adherence levels (see Table 5 below). 
Table 5: Evaluation of declared ratings

\begin{tabular}{|c|c|c|c|c|}
\hline & & Rating Based On Analysis Of Disclosures: & Self-Declared Rating: & Difference In Rating? \\
\hline \multirow{2}{*}{ Arcelormittal } & 2010 & $\mathrm{C}+$ & $\mathrm{C}+$ & $\mathrm{N}$ \\
\hline & 2011 & $\mathrm{~B}+$ & $\mathrm{B}+$ & $\mathrm{N}$ \\
\hline \multirow{2}{*}{ Anglo American } & 2010 & $\mathrm{~A}+$ & $\mathrm{A}+$ & $\mathrm{N}$ \\
\hline & 2011 & $\mathrm{~A}+$ & $\mathrm{A}+$ & $\mathrm{N}$ \\
\hline \multirow{2}{*}{ Anglo Platinum } & 2010 & $\mathrm{~B}+$ & $\mathrm{A}+$ & $\mathrm{Y}$ \\
\hline & 2011 & $\mathrm{~B}+$ & $\mathrm{A}+$ & $\mathrm{Y}$ \\
\hline \multirow{2}{*}{ Anglo Gold } & 2010 & $\mathrm{~B}+$ & A+ & $\mathrm{Y}$ \\
\hline & 2011 & $\mathrm{~B}+$ & $\mathrm{A}+$ & $\mathrm{Y}$ \\
\hline \multirow{2}{*}{$\begin{array}{l}\text { Arm - African } \\
\text { Rainbow }\end{array}$} & 2010 & $\mathrm{~B}+$ & $\mathrm{B}+$ & $\mathrm{N}$ \\
\hline & 2011 & $\mathrm{~B}+$ & $\mathrm{A}+$ & $\mathrm{Y}$ \\
\hline \multirow{2}{*}{ Bhp Billiton } & 2010 & $\mathrm{~A}+$ & $\mathrm{A}+$ & $\mathrm{N}$ \\
\hline & 2011 & $\mathrm{~B}+$ & $\mathrm{A}+$ & $\mathrm{Y}$ \\
\hline \multirow{2}{*}{$\begin{array}{l}\text { Exxaro Resources } \\
\text { Ltd }\end{array}$} & 2010 & $\mathrm{~B}+$ & $\mathrm{B}+$ & $\mathrm{N}$ \\
\hline & 2011 & $\mathrm{~B}+$ & $\mathrm{B}+$ & $\mathrm{N}$ \\
\hline \multirow{2}{*}{ Glodfields Ltd } & 2010 & $\mathrm{~A}+$ & $\mathrm{A}+$ & $\mathrm{Y}$ \\
\hline & 2011 & $\mathrm{~A}+$ & $\mathrm{A}+$ & $\mathrm{N}$ \\
\hline \multirow{2}{*}{ Harmony Gold } & 2010 & $\mathrm{~B}+$ & $\mathrm{B}+$ & $\mathrm{N}$ \\
\hline & 2011 & $\mathrm{~B}+$ & $\mathrm{B}+$ & $\mathrm{N}$ \\
\hline \multirow{2}{*}{ Implats } & 2010 & $\mathrm{~B}+$ & $\mathrm{B}+$ & $\mathrm{N}$ \\
\hline & 2011 & $\mathrm{~B}+$ & $\mathrm{B}+$ & $\mathrm{N}$ \\
\hline \multirow{2}{*}{$\begin{array}{l}\text { Kumba Iron Ore } \\
\text { Ltd }\end{array}$} & 2010 & $\mathrm{C}+$ & $\mathrm{C}+$ & $\mathrm{N}$ \\
\hline & 2011 & $\mathrm{~B}+$ & $\mathrm{A}+$ & $\mathrm{Y}$ \\
\hline \multirow{2}{*}{ Lonmin } & 2010 & $\mathrm{~A}+$ & $\mathrm{A}+$ & $\mathrm{N}$ \\
\hline & 2011 & $\mathrm{~A}+$ & $\mathrm{A}+$ & $\mathrm{N}$ \\
\hline \multirow{2}{*}{ Sasol } & 2010 & $\mathrm{~A}+$ & $\mathrm{A}+$ & $\mathrm{N}$ \\
\hline & 2011 & $\mathrm{~A}+$ & $\mathrm{A}+$ & $\mathrm{N}$ \\
\hline
\end{tabular}

It was found that in eight instances the companies were over-optimistic in giving themselves a higher rating than was justified. The differences in the self-declared ratings and the rating per this analysis were found exclusively on ratings where a company made a self-declared rating of ' $\mathrm{A}+$ ', while only meeting the criteria for ' $\mathrm{B}+$ '. It must be noted that per the Application Guidance (GRI, 2011f), an 'A' can only be awarded if the company reports on all the indicators included, or if not, the reason for omitting the indicators must be provided. Per analysis of the disclosures made, some disclosures were not made but no specific reason was given for the non-disclosure thus the 'A' rating was downgraded for purposes of this article.

Furthermore, several companies simply indicated that certain indicators have not been reported on, as it was considered to be immaterial, without explaining what measure of materiality was used. For the purposes of this article, such indicators were considered as disclosed seeing as a reason for non-disclosure was provided, but the question remains as to how this materiality is determined?

\section{CONCLUDING DISCUSSION}

\section{In summary}

Integrated reporting (on a global scale) is still very much in its infancy. The JSE, with Integrated Reports as a listing requirement, took on a leading role in emphasizing the importance of the wider categories of stakeholders. There is however, not much available in standardized reporting templates for these integrated reports, and the companies are pretty much left to their own devices in deciding what to report and what not to report. In the resource-based South African economy, the Mining and Minerals industry plays a key role in the broader regional and global economies. The key objective of this article was therefore to analyse and evaluate the integrated reports from this sector for the periods 2010 and 2011 in order to gauge their disclosures and adherences to the GRI's Framework in terms of social responsibility and sustainability. 
In addressing the objective regarding the key indicators considered important and material enough to report on, it was found that the selected mining companies returned quite balanced reports including economic, environmental, labour, human rights and social indicators. It does however; seem that the human aspect is slightly more important with the seven of the top 16 indicators focusing on labour and human rights. When considering the level of integration of the reports, a clear learning curve could be detected in how the level of integration has improved over the two years under consideration. Initially around half the companies submitted what can be considered adequately integrated reports in 2010 (seven out of 13). This has improved in 2011, with ten out of the 13 companies submitting adequately integrated reports. With regards to the ' $\mathrm{A}$ ', ' $\mathrm{B}$ ' or ' $\mathrm{C}$ '-ratings given to reports, the companies generally proved quite accurate in their self-declarations of ratings. What is interesting (and perhaps concerning) is that several ' $\mathrm{A}$ '-rated companies rated themselves higher than they should have been when considering the GRI guidelines. What makes this even more concerning is the fact that that these over-rated companies reports were independently assured to validate an 'A+'-rating. This brings the external assurer's report/assessment reliability and trustworthiness into question.

Determining what an acceptable reason for non-disclosure is, is considered a judgemental or grey area. As with many guidelines that are not statutory in nature, a 'disclose or explain' approach is often followed, but companies tend to regard a specific disclosure as 'disclosed' without a reason for non-disclosure. They then simply state that the indicator have not been disclosed. The reason for non-disclosure that can be accepted in order to deem the indicators as disclosed, is thus subject to opinion and cannot be regarded as incorrect. This does however clearly indicate that companies need to take more care in explaining reasons for non-disclosure of items if they want to selfdeclare an ' $\mathrm{A}+$ ' rating.

\section{Final remarks}

From a different but supportive perspective, the recent developments at the Lonmin Marikana platinum mine in South Africa raises questions on the measurement and disclosure of performance indicators. On August 16, 2012 disgruntled workers at the Marikana mine went on an unlawful and violent strike due to questionable living conditions at the mine (De Vos, 2012). The end-result of this strike became known as the Marikana Massacre; with numerous fatalities and wide spread unease in the South African mining industry (De Vos, 2012). Yet, Lonmin issued an exemplary integrated report which received an 'A+' rating in both 2010 and 2011. This raises the question: why was there no mention, in any integrated report, of the living conditions of workers or of the discontent of the employees of the Marikana mine? It appears that, in the case of Lonmin, only their positive non-financial performances were disclosed and the negative ones omitted. In addition to this the external assurance gained on the report is also questionable. One cannot but draw comparisons between Lonmin and the Enron / Arthur Anderson fiasco of a few years back. Is the limited assurance given on the content of the sustainability report sufficient or shouldn't an analysis on the completeness of such a report be conducted? Is it possible that the true purpose of the Integrated Report is being misconstrued and abused for self-promotional purposes and bragging rights?

\section{Recommendations}

Regardless of the form that sustainability takes, it affects everybody. The future of our economies, societies and the natural environments will be determined by how it is dealt with (Swift et al., 2007). Thus, clearly there is much room for improvement in the context of integrated reporting relating to the adherence to the Framework, especially when considering the more basic principles, including the boundary and scope of the report and maintaining a balance between reporting on both positive and negative aspects, as indicated in the Sustainability Reporting Guidelines and the Technical Protocol. It should be considered whether more attention should be placed on the basis on which the reports are prepared, rather than placing too much emphasis on ensuring to report on all standard disclosures. It is thus recommended that companies re-consider the basis of preparation of their sustainability and ultimately their integrated reports. Stricter adherence to the principles as set out by the GRI is necessary especially regarding the completeness and accuracy of the report.

In conclusion, according to Deloitte (2011b), it is inevitable that the world will move to the adoption of integrated reporting just as the world has moved towards the adoption of IFRS. The timing of adoption is however unclear, organizations that report on the complete range of issues may be seen more advanced than those which limit their reporting to mere financial information and limited sustainability disclosures. 


\section{Limitations of the study}

The results of this study are limited by the fact that the sample focuses on South African mining companies. Thus, firstly, the focus on the mining industry limits the application of the results of this study to companies in other industries. For other industries the sector supplement used in this study will not be applicable.

Secondly the results may not be applicable to other countries especially since the issuing of an integrated report would not necessarily be a listing requirement of the relevant stock exchange of such a country. Where the disclosure of sustainability information is voluntary, it is likely that only positive aspects will be disclosed and the scope of the report will be limited.

In addition to the above, this study focused on the standard disclosures as prescribed by the GRI in their Framework. Yet, per analysis of the relevant reports and per the findings above, it was clear that the more basic principles of the Framework were lacking (for example the setting of the boundary, scope and contents of the report). This being outside the scope of the research undertaken, limits the application of the results.

\section{Future research}

Considering the above limitations, further research can attempt to replicate a similar study in other sector of the JSE, from which cross-sector comparisons and best practices may be extrapolated.

\section{AUTHOR INFORMATION}

Tertia Hindley is currently an auditor employed at the global 'Big Four' Accounting firm Deloitte's offices in Johannesburg, South Africa. This article is based on the research conducted for her Masters in Commerce (Management Accountancy) degree at the North-West University's Potchefstroom campus in South Africa.

Professor Pieter W Buys is currently the Research Program Leader at the North-West University (South Africa) and holds two PhDs (Accountancy and Management Accountancy), two Masters Degrees (MComm and MBA), and he is also a US Certified Management Accountant (CMA). He has worked in the ERP and business consulting industry in Canada, the USA and South Africa for more than 15 years. He has published more than 40 articles in peer-reviewed and professional publications. His current research revolves around corporate social responsibility and resilience. E-mail: Pieter.Buys@nwu.ac.za (Corresponding author)

\section{REFERENCES}

1. Abouzeid, K.M. and Weaver, C.N. (1978). "Social Responsibility in the Corporate Goal Hierarchy". Business Horizons, June: 29-35.

2. Adams, C., Hill, W. Y. and Roberts. (1998). "Corporate Social Reporting Practices in Western Europe: Legitimating Corporate Behaviour?” British Accounting Review, 30:1-21.

3. Borkowski, S., Welsh, M.J. and Wentzel, K. (2010). Johnson \& Johnson: A model for sustainability reporting”, Strategic Finance, 29-37. September.

4. Chamber of Mines of South Africa. (2011). Annual Report 2010/2011 (year ended 30 June 2011). Johannesburg. 92p.

5. Daub, C.H. (2007). "Assessing the quality of sustainability reporting: an alternative methodological approach". Journal of Cleaner productions, 15:75-85.

6. Deloitte. (2009). "King III - September 2009: Every decision counts". https://www.saica.co.za/Portals/0/documents/Deloitte\%20King\%20III\%20Brochure.pdf Accessed on Sept $7^{\text {th }}, 2011$.

7. Deloitte. (2011a). “Integrated Reporting: A better view?". http://www.deloitte. com/assets/DcomGlobal/Local\%20Assets/Documents/Sustainability\%20and\%20Climate\%20Change/dttl_Deloitte_Integrate d_Reporting_a_better_view_Sep_2011.2.pdf Accessed on November $28^{\text {th }}, 2011$.

8. Deloitte. (2011b). "Integrated Reporting: Navigating your way to a truly Integrated Report. Edition 1".October 2011. 66p. 
9. Deloitte. (2012). Integrated Reporting: Navigating your way to a truly Integrated Report. Edition 2 February. 98p.

10. De Vos, P. (2012). "Some thoughts on the Marikana massacre". http://constitutionallyspeaking.co.za/somethoughts-on-the-marikana-massacre/ Accessed on August 29, 2012

11. Doane, D. and Macgillivray, A. (2001). Economic Sustainability; The Business of Staying in Business. The Sigma Project. 52p

12. Eccles, R. G. and Krzus, M.P. (2010). "Integrated reporting for a sustainable strategy". Financial executive, 29-32. March.

13. Elkington, J. (1997). Cannibals with Forks: The Triple bottom line of 21st century business. United Kingdom: Capstone. 410p.

14. Global Reporting Initiative. (2011a). "What is GRI?". http://www.globalreporting.org/AboutGRI/WhatIsGRI/ Accessed on Sept 6 ${ }^{\text {th }}, 2011$.

15. Global Reporting Inisiative. (2011b). "Vision and Mission". http://www.globalreporting.org/AboutGRI/WhatIsGRI/VisionAndMission.htm Accessed on Sept 6 ${ }^{\text {th }}, 2011$.

16. Global Reporting Initative. (2011c). "What is the GRI reporting framework?". http://www.globalreporting.org/ReportingFramework/ReportingFrameworkOverview/ Accessed on Sept $15^{\text {th }}, 2011$.

17. Global Reporting Initiative. (2011d). "Sector Supplements". http://www.globalreporting.org/ReportingFramework/SectorSupplements/ Accessed on Sept 15 ${ }^{\text {th }}, 2011$.

18. Global Reporting Initiative. (2011e). "Sustainability reporting Guidelines \& Mining and Metals Sector Supplement". http://www.globalreporting.org/ReportingFramework/GuidelinesMineralsandMetalsSupplements/ Accessed on Sept $15^{\text {th }}, 2011$.

19. Global reporting Initiative. (2011f). "GRI Application Levels: http://www.globalreporting.org/ReportingFramework/Applicationlevels/ Accessed on Sept 15 ${ }^{\text {th }}, 2011$.

20. GRI see Global reporting Initiative

21. Ho, L.J. and Taylor, M.E. (2007). "An Empirical Analysis of Triple Bottom-Line Reporting and its Determinants: Evidence from the Unites States and Japan”. Journal of International Financial and Accounting, 18(2):123-150.

22. King III see King Code of Governance for South Africa.

23. King Code of Governance for South Africa. (2009). SAICA Legislation Handbook 2010/2011. Volume 3.

24. Lev, B. and Zarowin, P. (1999). "The Boundaries of Financial Reporting and How to Extend Them". Journal of Accounting Research, 37(2):353-385, Autumn.

25. National Treasury. (2010). Discussion Paper for public comment. Reducing Greenhouse gas emissions: The Carbon Tax option. Available at: http://www.treasury.gov.za/public\%20comments/Discussion\%20Paper\%20Carbon\%20Taxes\%2081210.pd $\underline{f}$

26. Oberholzer, A. (2011). "Integrated reporting: Why should you care?" Communication World, 48, Sep-Oct.

27. Pounder, B. (2011). "Trends in sustainability reporting". Strategic Finance, 21-23 December.

28. Rogers, M. and Ryan, R. (2001). "The Triple Bottom Line for Sustainable Community Development". Local Environment, 6(3):279-289

29. SAICA. (2011). Sustainability Reporting and Integrated Reporting. https://www.saica.co.za/TechnicalInformation/SustainabilityandIntegratedReporting/SustainabilityReportin gandIntegratedReporting/tabid/1653/language/en-ZA/Default.aspx Accessed on Sept 15 $5^{\text {th }}, 2011$.

30. SouthAfrica.info. (2012). "Key sectors - Mining and minerals in South Africa". http://www.southafrica.info/business/economy/sectors/mining.htm Accessed on March $7^{\text {th }}, 2012$

31. Swift, G., Bennet, B., Brown, J., Casey, P., Collins, S., Gray, T., McGuiness, W., Maher, R., Simpkins, K. and Whitehouse, P. (2007). "Sustainable development reporting: an idea whose time has come". Chartered Accountants Journal, 8-13. Oct.

32. Two Tomorrows. (2009). "What is CSR?". http://www.twotomorrows.com/news/what-csr/ Accessed Sept $6^{\text {th }}, 2011$. 